DOI https://doi.org/10.15589/znp2021.1(484).11

УДК 004:371.213.8

\title{
FORECASTING RATION OF THE HUMAN NUTRITION WITH THE HELP OF IT TECHNOLOGY
}

\section{ПРОГНОЗУВАННЯ РАЦІОНУ ХАРЧУВАННЯ ЛЮДИНИ ЗА ДОПОМОГОЮ ІТ-ТЕХНОЛОГІЙ}

Iryna A. Getman ${ }^{1}$

getman_irina@ukr.net

ORCID: 0000-0003-1835-4256

Tamara V. Kukhtyk ${ }^{2}$

ditmtvk@icloud.com

ORCID: 0000-0002-2000-3669

Maryna A. Derzhevetska ${ }^{3}$

marina_d.a@ukr.net

ORCID: 0000-0002-9952-4992

\author{
I. А. Гетьман ${ }^{1}$, \\ канд. техн. наук, доцент
}

Т. В. Кухтик ${ }^{2}$, докт. техн. наук, професор

М. А. Держевецька ${ }^{3}$, канд. екон. наук

\author{
${ }^{1}$ Donbas State Engineering Academy, Kramatorsk \\ ${ }^{2}$ Donbass Institute of Technology and Management Higher Educational Institution \\ “Academician Yuriy Bugay International Scientific and technical university”, Kramatorsk \\ ${ }^{3}$ Donetsk National Medical University, Kramatorsk \\ ${ }^{1}$ Донбаська державна машинобудівна академія, м. Краматорськ \\ ${ }^{2}$ Донбаський інститут техніки та менеджменту Міжнародного науково-технічного університету \\ імені академіка Юрія Бугая, м. Краматорськ \\ ${ }^{3}$ Донецьький національний медичний університет, м. Краматорськ
}

\begin{abstract}
The issue of developing a software package for forecasting ration of the human diet was considered. It was proved that the problem of healthy eating is relevant for our country. The analysis of types of existing software products, their advantages and disadvantages were carried out. And it was established that users are more often interested in a daily diet, than use of other calculations of food at distribution of parameters and restrictions. The analysis of principles and methods of diet forecasting were carried out. The use of the Harris-Benedict formula and the fastest descent gradient method for calculating the daily caloric intake for humans were considered. It was determined that the mathematical model for the calculation was based on the following factors and information from the human life for which the calculation of the diet will take place: human sex; human age; human height; human weight; whether physical activity was included in his life. However, we should not forget about the taste of each individual, so the main feature of the developed model was that each user of the proposed software product had the opportunity to choose from a list of only those products that he prefers, or that do not cause him any allergies and adverse effects on body health. As a result, the diet would be selected and built for the selected list of products. The main task was the automatic filling database information about base products, then the implementation of the modified method for calculating the daily diet, which then can be used for other analog sites (possibly with a profit in the future). The description of designing and development of the software complex realizing forecasting of a food ration of the person was made, and also the user's guide was offered. The Ruby on Rails framework was chosen for development, which allowed to implement the algorithm of the developed mathematical model in the shortest possible time, taking into account all modern principles of building applications of such a plan.
\end{abstract}

Key words: nutrition; diet; gradient descent method; Harris-Benedict formula; calories; proteins; fats; carbohydrates; daily allowance; foods; activity; caloric content; healthy eating; optimization.

Анотація. Розглянуто питання розробки програмного комплексу для прогнозування раціону харчування людини. Доведено, що проблема здорового харчування є актуальною для нашої країни. Проведено аналіз видів наявних програмних продуктів, їх переваги та недоліки. Встановлено, що користувачі найчастіше цікавляться денним раціоном харчування, ніж використанням інших розрахунків харчування під час розподілу параметрів 


\section{КОМП'ЮТЕРНІ НАУКИ ТА ІНФОРМАЦІЙНІ ТЕХНОЛОГІЇ №1-2021}

і обмежень. Проведено аналіз принципів та методів прогнозування раціону харчування. Розглянуто використання формули Гарісса-Бенедикта та градієнтного метода найшвидшого спуску для розрахунку добової норми калорій для людини. Визначено, що математична модель для розрахунку грунтується на наступних факторах та інформації з життя людини, для якого буде відбуватися розрахунок раціону: стать людини; вік; зріст; вага; чи включені в іï життя фізичні навантаження. Однак не варто забувати про смакові індивідуальні особливості кожної людини, тому головною особливістю розробленої моделі $є$ те, що кожен користувач запропонованого програмного продукту має можливість вибрати зі списку тільки ті продукти, які він вважає кращими для себе, або які не викликають у нього будь-яких алергій і негативного впливу на здоров'я організму. В результаті раціон буде підібраний і побудований для вибраного списку продуктів. Основним завданням $\epsilon$ автоматичне наповнення бази даних інформацією про базу продуктів, потім реалізація модифікованого методу для розрахунку денного раціону харчування, які потім можуть бути використані для інших аналогових сайтів (можливо 3 отриманням прибутку в майбутньому). Зроблено опис проєктування та розробки програмного комплексу, що реалізує прогнозування раціону харчування людини, а також запропоновано керівництво користувача. Для розробки був обраний фреймворк Ruby on Rails, який дозволив у найкоротші терміни реалізувати алгоритм розробленої математичної моделі з огляду на всі сучасні принципи побудови додатків подібного плану.

Ключові слова: харчування; раціон; метод градієнтного спуску; формула Гарріс-Бенедикта; калорії; білки; жири; вуглеводи; добова норма; продукти; активність; калорійність; здорове харчування; оптимізація.

\section{ПОСТАНОВКА ЗАДАЧІ}

Правильне харчування - це такий спосіб харчування, за якого підсумком цього процесу є зміцнення та поліпшення здоров'я, фізичних і духовних сил людини, попередження та лікування різних захворювань, уповільнення процесів старіння, тобто правильне харчування - це здорове харчування. Здорове харчування вимагає споживання з їжею необхідної кількості енергії, а також достатнього споживання незамінних харчових речовин, до числа яких належать вітаміни, мікроелементи, незамінні амінокислоти і незамінні жирні кислоти. Потреби людини в різних харчових речовинах пов'язані з іiї енергетичними запитами, віком, статтю, ростом і вагою. На потребу в харчових речовинах впливають також такі фактори способу життя, як рівень фізичної активності, стрес, куріння, споживання алкоголю. Жоден продукт окремо не містить всіх харчових речовин в оптимальних кількостях і правильних співвідношеннях. Ось чому здорове харчування можливо лише у разі споживання різноманітних харчових продуктів. Проблема здорового харчування $\epsilon$ актуальною для нашої країни. Харчування має бути регулярним, різноманітним, повноцінним і збалансованим за набором життєво необхідних речовин (білки, жири, вуглеводи).

Запропонована модель призначена для того, щоб допомогти людині підібрати список продуктів, який необхідно вжити для досягнення здорового раціону харчування, що, можливо, допоможе запобігти захворюванням, пов'язаним з ожирінням або 3 органами травлення. Модель враховує такі параметри, як стать, вік, зріст, вага і щоденна активність людини. Це дає змогу отримати більш точний результат і допоможе скласти правильне співвідношення необхідних організму речовин (білків, жирів, вуглеводів).

\section{АНАЛІЗ НАЯВНИХ ПРОГРАМНИХ ПРОДУКТІВ}

Прогнозування подій у харчовій сфері на цей момент користується попитом серед любителів «ідеального харчування». Однак не завжди людина впевнена у своєму виборі і їй доводиться шукати допомогу. У зв'язку з цим було розроблено кілька десятків ресурсів, які в автоматичному режимі дозволяють виробляти такі розрахунки. Так само слід зазначити, що кожна подібна система неповторна і унікальна, бо алгоритмів виведено сотні і методи прогнозування можуть докорінно відрізнятися. Однак всі вони мають однакову мету - зробити процес передачі інформації від системи до користувача як можна зручнішим. Другий аспект, який хвилює користувачів, це рівень вгадування результатів.

За запитом «розрахунок раціону харчування» пошукова система Google видає 54000 результатів, а пошукова система Яндекс - 32000000 результатів, що говорить про актуальність цієї теми (рис. 1).

Проаналізуємо схожі додатки з цього запиту і подивимося, які послуги вони можуть запропонувати.

Перше місце у списку займає pecypc http://dolgieleta.ru/. Цей ресурс дозволяє онлайн розрахувати 3 точністю $\pm 10 \%$ необхідну кількість нутрієнтів під час складання меню для вашого щоденного харчування або приготування певного блюда. Змінюючи інгредієнти, можна конструювати рецепти страв з урахуванням включення в ваш раціон всіх необхідних білків, жирів, вуглеводів, вітамінів, мікро- та макроелементів, амінокислот, флавоноїдів.

За допомогою програми «Раціон» ви зможете забезпечити своєму організму збалансоване харчування, позбавивши його нестачі одних і надлишку інших нутрієнтів, що надходять до нашого організму $з$ продуктами, які ми щодня вживаємо. Необхідно зробити суттєве зауваження до деяких обмежень 
у програмі. Полягають вони в наступному: під час вибору продуктів необхідно враховувати їх застосування в свіжому або приготованому вигляді. Некоректним буде результат, якщо будуть обрані одночасно продукти, які пройшли теплову обробку, і продукти без такої обробки. Інформація про деякі свіжі (сирі) продукти у базі є суто довідковою і не відстежує зміну кількості нутрієнтів під час їх теплової і ферментативної обробки. В іншому разі помилка в результатах розрахунку може скласти $\pm 30 \%$ і більше. Але значним плюсом є те, що програма абсолютно безкоштовна.

Однак найбільш цікавий ресурс, який найближче нагадує запропонований алгоритм і тему, - це відомий $\mathrm{i}$ популярний http://health-diet.ru/, який так само використовує формули Гарісса-Бенедикта. Цей ресурс працює на основі певних обов'язкових правил, яких необхідно дотримуватися. Кожне правило - це вхідний параметр, який у підсумку допомагає більш точно розрахувати результат, який ми отримаємо. Головні переваги цього ресурсу: ніяких жорстких дієт; тільки правда і робота над собою; теорія і база знань; щоденник харчування; щоденник тренувань; спільнота.

Також на сайті вказані особливості особистого щоденника: підрахунок калорійності, білків, жирів, вуглеводів, вітамінів, мінералів та інших нутрієнтів за прийомами їжі і за день; найбільш повна база продуктів і страв, що включає близько 9000 найме- нувань 3 докладним хімічним складом; індивідуальні щоденники харчування для кожного члена сім'ї; додавання своїх продуктів і рецептів з урахуванням кулінарної обробки; пошук серед продуктів-лідерів найкорисніших продуктів 3 максимальним вмістом вітамінів і мінералів. Цей ресурс пропонує великий спектр можливостей, що робить його унікальним для кожного користувача. Також цей ресурс зручний тим, що виводить графічну статистику ваших змін на сайті, яка дозволяє спостерігати за вашими успіхами. Невіддільною частиною $є$ «калькулятор рецептів», який дозволяє зробити вибір кулінарної обробки: варіння, смаження, тушкування та інші. Також корисною $є$ функція визначення рейтингу рецепта - його корисності. Публікація рецепта в співтоваристві самого сайту. Мінусом сайту можна вважати те, що не весь функціонал надається безкоштовно.

\section{МЕТА ДОСЛІДЖЕННЯ}

Метою роботи $\epsilon$ - проаналізувати принципи та методи прогнозування раціону харчування та створити програмний комплекс, який реалізує прогнозування раціону харчування людини, використовуючи формулу Гарісса-Бенедикта для розрахунку добової норми калорій для людини.

\section{ОСНОВНИЙ МАТЕРІАЛ}

Програмний продукт має назву "HealthyFood". Зовнішній вигляд головної сторінки ПП наведено на

\section{Google \\ розрахунок раціону харчування

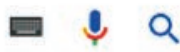

Все Новости Картинки Видео Карты Ещё Настройки Инструменты
Результатов: примерно $54000(0,38$ сек.) \\ Розрахунок (підрахунок калорій). Таблиця калорій » Жіночий світ ywoman.ru/.../rozrahunok-pidrahunok-kalorij-tablicja-kalori... - Перевести эту страницу При розрахунку калорійності харчового раціону дитини враховується, що 2/3 харчових калорій витрачається на процеси росту, тому на $1 \mathrm{kr}$ ваги тіла ... \\ МЕТОДИКА РОЗРАХУНКУ ЕНЕРГОВИТРАТ ЛЮДИНИ ТА ІІ ... intranet.tdmu.edu.ua/.../05.\%20Методика\%20розрахунку\%... - Перевести эту страницу Харчовий раціон людини складається із харчових продуктів, які містять білки, жири, вуглеводи, вітаміни і в достатній кількості воду. Поеднання харчових ... \\ Харчування в поході або як підготувати продукти для походу ... gotothegoal.com , Блог , Статті , Підготовка до походів - Перевести эту страницу 18 июн. 2014 г. - Розподіл раціону харчування на добу. Приблизно ... вживання! Каші, крупи беремо приблизно з розрахунку 100 -125 грам на людину! \\ Раціональне харчування zdorov.com.ua/nutrition.html - Перевести эту страницу \\ Тільки різноманітні продукти харчування в раціоні забезпечують його ... "Ratio" - в перекладі з грецької означає розум, наука, а також розрахунок.}

Рис. 1. Пошукова видача Google за запитом «розрахунок раціону харчування» 


\section{КОМП’ЮТЕРНІ НАУКИ ТА ІНФОРМАЦІЙНІ ТЕХНОЛОГІЇ № 1 - 2021}

рисунку 2.

Далі користувач переходить на сторінку розрахунку добового раціону харчування і бачить сторінку, зображену на рисунку 3 .

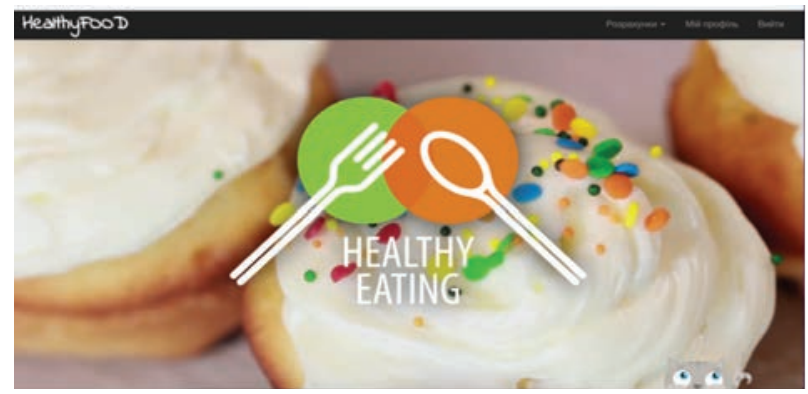

Рис. 2. Головна сторінка ПП для прогнозування раціону харчування
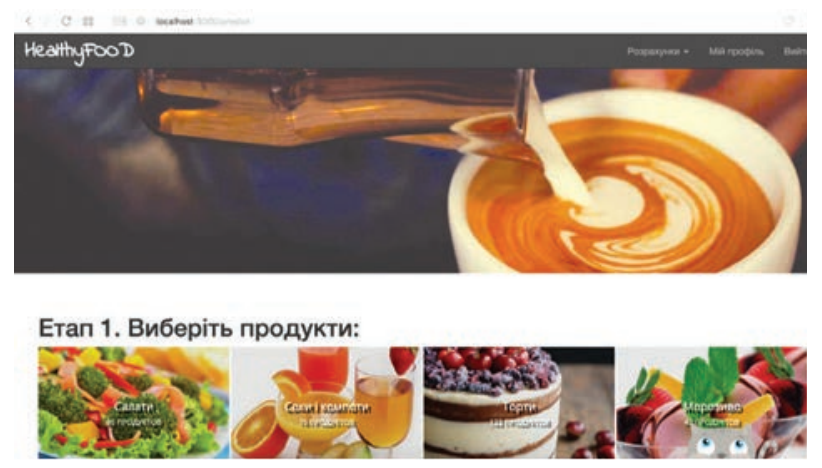

Рис. 3. Головна сторінка ПП для прогнозування раціону харчування

На цій сторінці користувачеві пропонується вибрати необхідні параметри і виконати розрахунок. Розглянемо детальніше кожен з елементів і опишемо їх поведінку.

Для початку користувачеві необхідно обрати продукти. Для цього він спочатку вибирає потрібну категорію, після чого отримує список можливих продуктів харчування (рис. 4).

Після того, як користувач визначився зі списком можливих продуктів харчування, йому пропонується ввести додаткову інформацію (обмеження) про себе (рис. 5).

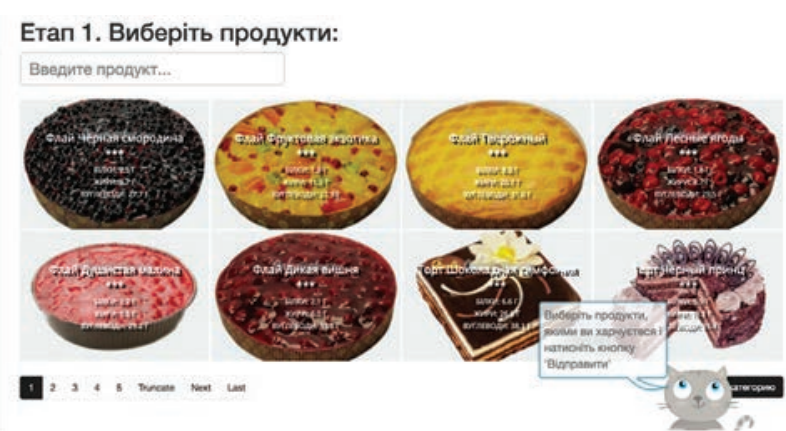

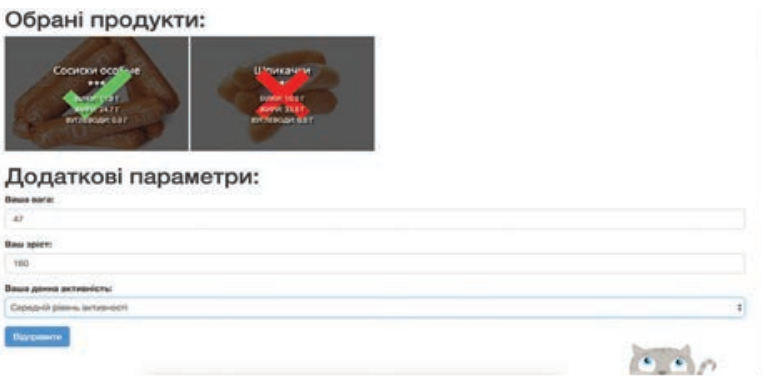

Рис. 5. Вибрані продукти і додаткові параметри на сторінці прогнозування раціону харчування

Після того, як користувач натисне на кнопку «Відправити», він отримає готовий раціон харчування на день. Однак якщо ви не є зареєстрованим користувачем, система автоматично перенаправляє його на модальне вікно з реєстрацією, після відбувається перехід на акаунт користувача, в якому необхідно заповнити всі необхідні поля для точності майбутніх розрахунків. Цю анкету можна роздрукувати або зберегти.

Результати роботи програмного продукту відображені на рисунках 6-10.

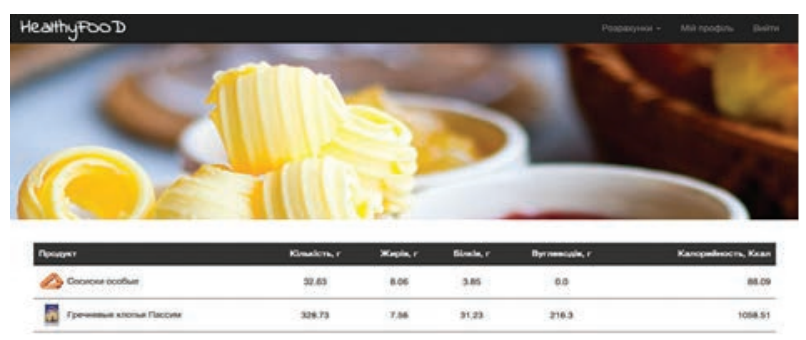

Рис. 6. Таблиця с результатами прогнозування

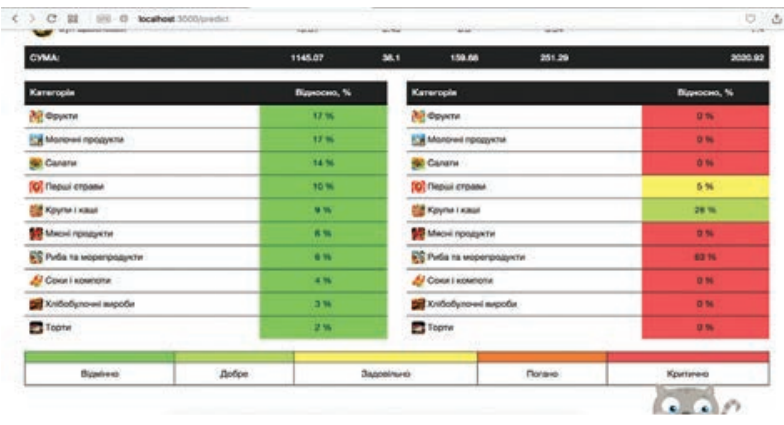

Рис. 7. Загальна порівняльна характеристика харчування за добу

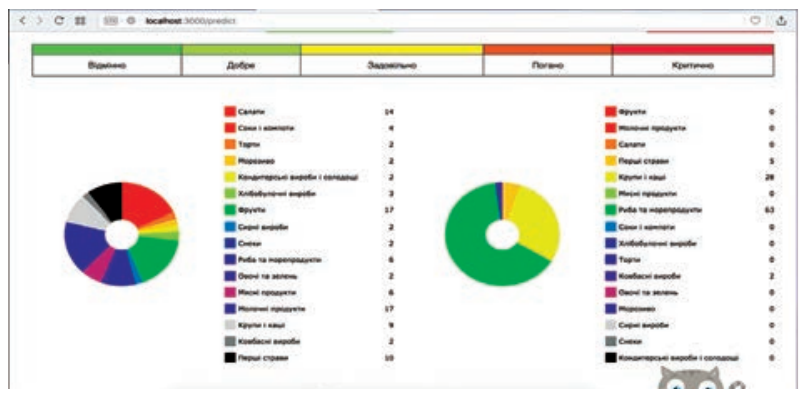

Рис. 8. Результат розрахунку раціону харчування людини радіальні-діаграми показують відсоткове відношення

Ця сторінка остання і не має більше ніяких еле- 


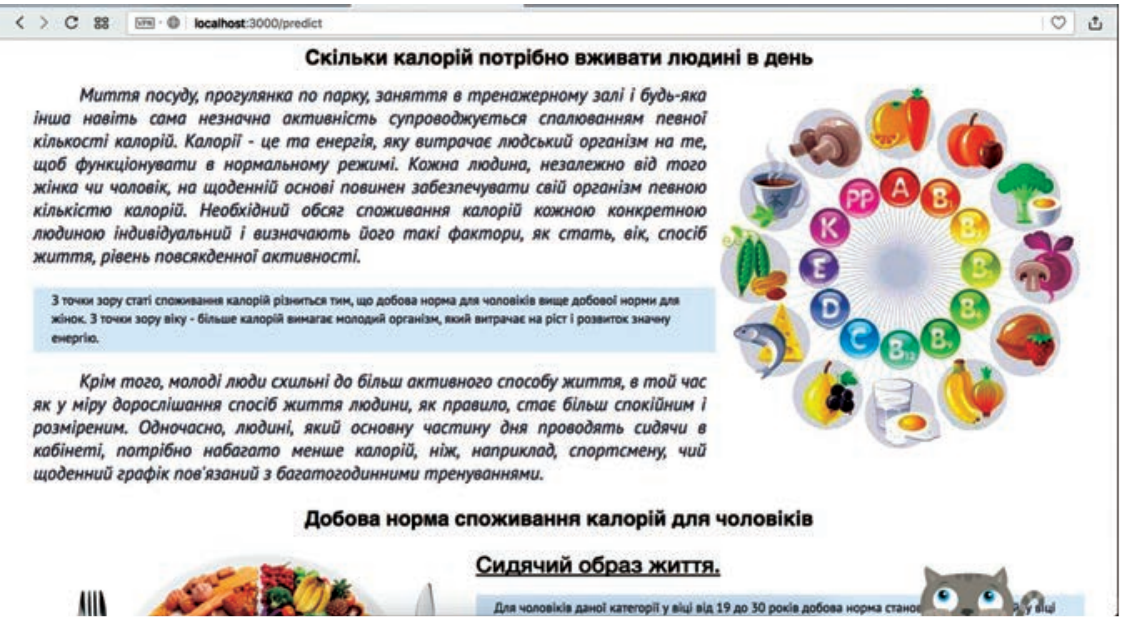

Рис. 9. Результат розрахунку раціону харчування людини - інформативна частина

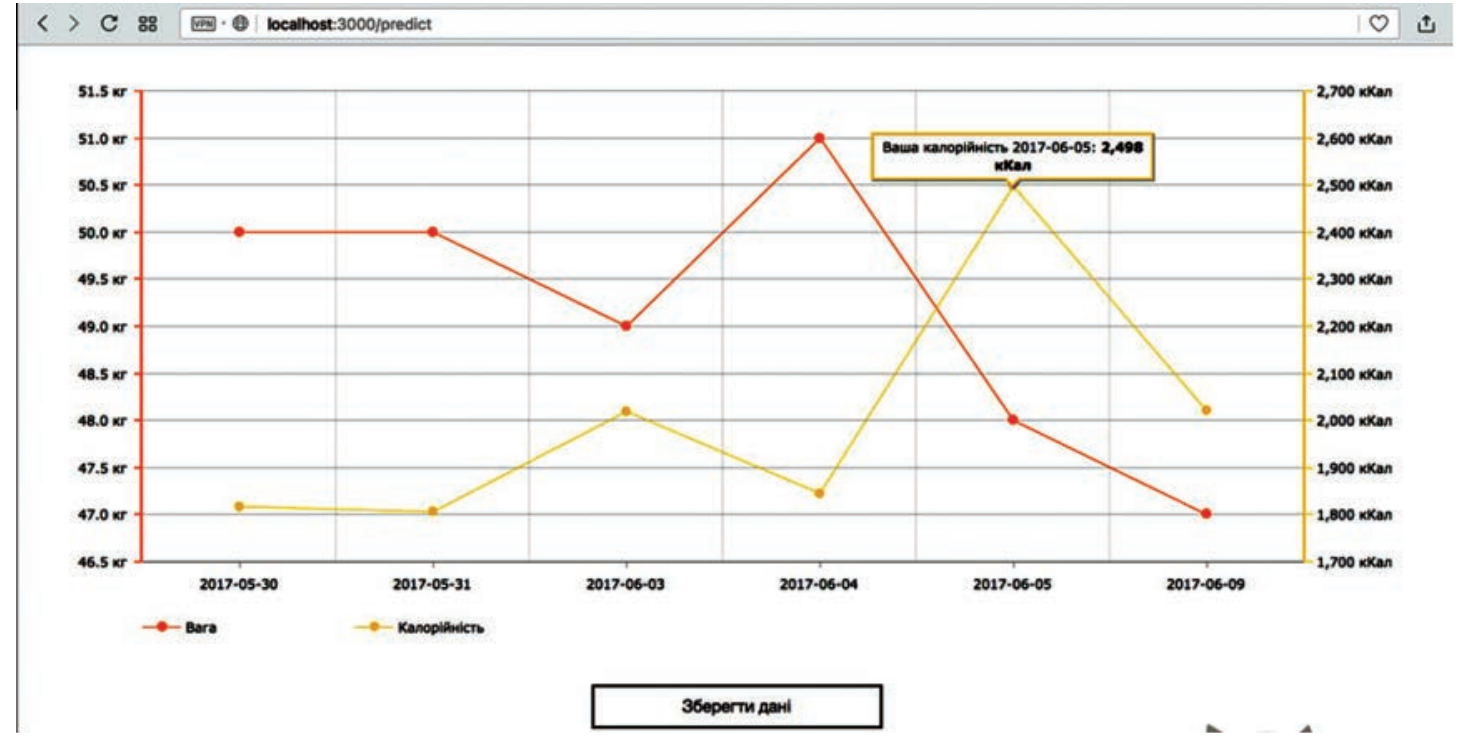

Рис. 10. Результат розрахунку раціону харчування людини - діаграма відносності калорій та ваги

ментів управління.

Для початку роботи з додатком користувач повинен мати Unix-систему (Linux або MacOS) з встановленим Ruby on Rails i заздалегідь підготовленою папкою з файлами програми. Далі за допомогою команди rails s необхідно запустити сервер. Після виконання вищевказаних дій користувач може в браузері зайти за спеціально адресою, де він зможе працювати 3 додатком. Або для початку необхідно наповнити базу даних категорій продуктів і самих продуктів. Далі, після того, як дані будуть введені, на сторінці розрахунку раціону харчування необхідно вибрати список продуктів і обмежень і відправити форму на сервер, отримавши результат на екран. Для повторення виконання прогнозування необхідно повернутися на сторінку розрахунку раціону харчування і повто- рити всі дії.

\section{ВИСНОВКИ}

У результаті виконання роботи з розробці програмного комплексу для прогнозування раціону харчування людини були досліджені і застосовано алгоритм градієнтного методу найшвидшого спуску та формула Гарісса-Бенедикта. Основним завданням, яке розв'язується розробленим програмним продуктом, $є$ автоматичне наповнення бази даних інформацією про базу продуктів. Після цього є можливою реалізація модифікованого (під час виконання цього проєкту) методу для розрахунку денного раціону харчування, який потім може бути використаний для інших аналогових сайтів (можливо з отриманням прибутку в майбутньому). Так само були проаналізовані аналоги створюваного програмного продукту, їх переваги 


\section{КОМП'ЮТЕРНІ НАУКИ ТА ІНФОРМАЦІЙНІ ТЕХНОЛОГІЇ №1ロ 2021}

та недоліки і встановлено, що користувачі найчастіше цікавляться денним раціоном харчування, ніж використанням інших розрахунків харчування під час розподілу параметрів і обмежень. Таким чином, було адаптовано програмний продукт під кожного унікального користувача. Безумовно, одним з основних завдань у галузі розробки програмного комплексу було написання якомога більше простого і швидкого додатка. Для розробки був обраний фреймворк Ruby on Rails, який дозволив в найкоротші терміни реалізувати алгоритм розробленої математичної моделі 3 огляду на всі сучасні принципи побудови додатків подібного плану. В результаті було отримано повноцінний продукт, готовий до користування кінцевими споживачами.

\section{REFERENCES}

[1] Menyu pravilnogo harchuvannya [Proper nutrition menu], available at: http://iamantltd.com.ua/uk/experts/krasotai-pravilnoe-pitanie/134-menyu-pravilnogo-pitaniya (Accessed 10 May 2020).

[2] Harris, JA, Benedict, FG (1918), A Biometric Study of Human Basal Metabolism. Proceedings of the National Academy of Sciences of the United States of America, 4 (12): 370-3.

[3] Harris Benedict formula for women and men, available at: GottaSport.com. (Accessed 10 May 2020).

[4] Mifflin, M.D., St Jeor, S.T., Hill, L.A., Scott, B.J., Daugherty, S.A., Koh, Y.O. (1990), A new predictive equation for resting energy expenditure in healthy individuals. The American Journal of Clinical Nutrition, 51 (2): 241-7.

[5] Gill, F., Myurrei,U., Rait M. (1985). Praktichna optimizaciya [Practical Optimization]. Mir [World], Moscow, Russia.

\section{СПИСОК ВИКОРИСТАНОЇ ЛІТЕРАТУРИ}

[1] Меню правильного харчування. URL: http://diamantltd.com.ua/uk/experts/krasota-i-pravilnoe-pitanie/134-menyupravilnogo-pitaniya (дата звернення 10.05.2020).

[2] Harris JA, Benedict FG (1918). "A Biometric Study of Human Basal Metabolism”. Proceedings of the National Academy of Sciences of the United States of America 4 (12): 370-3.

[3] Harris Benedict formula for women and men, available at: GottaSport.com. (дата звернення 10.05.2020).

[4] Mifflin MD, St Jeor ST, Hill LA, Scott BJ, Daugherty SA, Koh YO (1990). "A new predictive equation for resting energy expenditure in healthy individuals". The American Journal of Clinical Nutrition 51 (2): 241-7.

[5] Гилл Ф., Мюррей У., Райт М. Практична оптимізація - Practical Optimization. Москва : Мир, 1985.

(C) Гетьман I. А., Кухтик Т. В., Держевецька М. А. Дата надходження статті до редакції: 09.03.2021 Дата затвердження статті до друку: 23.03.2021 